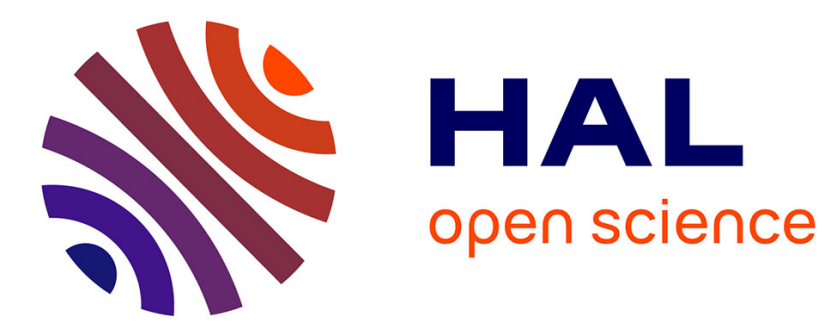

\title{
Crystallized V2O5 as oxidized phase for unexpected multicolor electrochromism in V2O3 thick film
}

Issam Mjejri, Manuel Gaudon, Giljoo Song, Christine Labrugère, Aline Rougier

\section{- To cite this version:}

Issam Mjejri, Manuel Gaudon, Giljoo Song, Christine Labrugère, Aline Rougier. Crystallized V2O5 as oxidized phase for unexpected multicolor electrochromism in V2O3 thick film. ACS Applied Energy Materials, 2018, 1 (6), pp.2721-2729. 10.1021/acsaem.8b00386 . hal-01831870

\section{HAL Id: hal-01831870 https://hal.science/hal-01831870}

Submitted on 6 Jul 2018

HAL is a multi-disciplinary open access archive for the deposit and dissemination of scientific research documents, whether they are published or not. The documents may come from teaching and research institutions in France or abroad, or from public or private research centers.
L'archive ouverte pluridisciplinaire HAL, est destinée au dépôt et à la diffusion de documents scientifiques de niveau recherche, publiés ou non, émanant des établissements d'enseignement et de recherche français ou étrangers, des laboratoires publics ou privés. 


\title{
Crystallized $\mathrm{V}_{2} \mathrm{O}_{5}$ as Oxidized Phase for Unexpected Multi-Color Electrochromism in $\mathrm{V}_{2} \mathrm{O}_{3}$ thick film
}

\author{
Issam Mjejri $^{\dagger \ddagger}$, Manuel Gaudon ${ }^{\dagger \ddagger}$, Giljoo Song ${ }^{\dagger \ddagger}$, Christine Labrugère^ and Aline Rougier ${ }^{\dagger \neq *}$ \\ ${ }^{\dagger}$ CNRS, ICMCB, UMR 5026, F-33600 Pessac, France \\ łUniv. Bordeaux, ICMCB, UMR 5026, F-33600 Pessac, France \\ ^CNRS, Université de Bordeaux, PLACAMAT UMS 3626, F-33600 Pessac, France
}

*Corresponding Author: aline.rougier@icmcb.cnrs.fr, ICMCB-CNRS, 87 avenue du Dr Albert Schweitzer, 33608

Pessac cedex, France

KEYWORDS. Electrochromism materials; Vanadium oxides; Polyol synthesis; Doctor Blade; Optical properties

\begin{abstract}
Our e-connected society is eager to develop devices with tunable colors. Electrochromic materials, able to modify their optical properties under an applied voltage, offer a smart solution. In the present study, we have successfully synthesized two vanadium oxide powders from a polyol mediated synthesis and powder suspensions were coated on glass/ITO substrates by doctor blading. The electrochemical and optical properties of the $\mathrm{V}_{\mathrm{x}} \mathrm{O}_{\mathrm{y}}$ films are investigated by cyclic voltammetry (CV) coupled with insitu UV-Visible spectroscopy. Both $\mathrm{V}_{2} \mathrm{O}_{5}$ and $\mathrm{V}_{2} \mathrm{O}_{3}$ films exhibit reasonably good cycling stability, significant reflectance modulation, high optical contrast and good memory effects revealing the unknown EC properties of $\mathrm{V}_{2} \mathrm{O}_{3}$. The similar green $\rightleftarrows$ blue $\rightleftarrows$ orange reversible color changes for both vanadium oxides appears suitable for display application. Then, the evolution of the vanadium cation oxidation states and of the structure of $\mathrm{V}_{2} \mathrm{O}_{5}$ and $\mathrm{V}_{2} \mathrm{O}_{3}$ upon cycling are analyzed by ex-situ XPS and ex-situ XRD (at grazing incident angle). This work highlights a robust and novel scenario upon cycling, nearly the same whatever the raw film composition that shows, for each cycle, the crystallization of $\mathrm{V}_{2} \mathrm{O}_{5}$ upon oxidation, followed by amorphization upon reduction.
\end{abstract}

\section{INTRODUCTION}

With the rapid development of clean renewable energy and increasing demands for multi-electrochromic devices, tremendous efforts have been pursued to find alternative materials that modulate several colors depending on redox potential with high performances and low cost. ${ }^{1-5}$ For many years electrochromic (EC) materials have been of great academic and commercial interest and recognized as one of the key "green" technologies for sustainability and energy savings in building environments. 6,7

Over the past decades, tungsten oxide $\left(\mathrm{WO}_{3}\right)$, that switches to blue upon reduction, has been extensively studied due to its outstanding electrochromic properties. ${ }^{8-10}$ It is currently used in most of the commercial applications based on the modulation of transmittance including in particular smart windows. Aiming at enlarging the range of available colors well suitable for displays applications, intensive researches have been focusing on alternative materials, including polymers ${ }^{11}$ or more recently Metal Organic Framework. ${ }^{12}$ In the oxide family, $\mathrm{V}_{2} \mathrm{O}_{5}$ has come up as a promising electrochromic material for device application because of its multi-color reported in various electrolytes. ${ }^{13-17}$ Besides, its abundance and layered structure facilitate the exchange of large amount of Li cations. ${ }^{18-20}$

Vanadium cation exists in $\mathrm{V}^{2+}, \mathrm{V}^{3+}, \mathrm{V}^{4+}$ and $\mathrm{V}^{5+}$ states in vanadium oxide compounds that are categorized as single and mixed oxides based on Magneli $\left(\mathrm{V}_{\mathrm{n}} \mathrm{O}_{2 \mathrm{n}-1}\right)$ and Wadsley $\left(\mathrm{V}_{2 \mathrm{n}} \mathrm{O}_{5 \mathrm{n}-}\right.$ 2) series. ${ }^{21}$ Indeed, the multivalent nature of vanadium cation associated with distinct colors earns it the name of the Norse Goddess of beauty, Vanadis. Meanwhile, the coexistence of various oxidation numbers offers a drastic challenge to prepare with a stoichiometric target only one single phase, especially as vanadium oxide thin or thick films. The uses of vanadium dioxide: $\mathrm{VO}_{2}$ and vanadium sesquioxide: $\mathrm{V}_{2} \mathrm{O}_{3}$ are more popular than other $\mathrm{V}_{\mathrm{x}} \mathrm{O}_{\mathrm{y}}$ forms due to their unique reversible metal-insulator phase transition (MIT). ${ }^{22,}{ }^{23} \mathrm{~V}_{2} \mathrm{O}_{3}$ phase is known for its phase transition coupled with a magnetic disordering versus temperature. ${ }^{23,}{ }^{24}$ In this work, it will be shown that, next to the magnetic properties, the $\mathrm{V}_{2} \mathrm{O}_{3}$ phase is characterized by unexpected electrochromic properties further proving the high diversity of the physico-chemical properties of vanadium oxides. On the contrary, due to its stability and great properties, $\mathrm{V}_{2} \mathrm{O}_{5}$ has been mentioned many times in literature as positive electrode for lithium/sodium batteries or optical batteries (electrochromic device). However, despite the diversity of papers, dealing with the electrochromic properties of $\mathrm{V}_{2} \mathrm{O}_{5}$ films, explanations on the observed preferential crystallographic orientation and the origin of the color changes remain a subject of debate. ${ }^{25}$ Besides, $\mathrm{V}_{2} \mathrm{O}_{5}$ is one of the only materials that clearly shows both anodic and cathodic colorations as a result of the occurrence of various oxidation states associated with different colors. ${ }^{26}$ Indeed, depending on the vanadium oxidation number, $\mathrm{V}_{2} \mathrm{O}_{5}$ based electrochromic films exhibit several colors, thus offering the possibility of obtaining multicolor displays. 
Several synthetic ways such as microemulsion-mediated systems, arc discharge, laser-assisted catalysis growth, solution, vapor transport, and solvothermal and hydrothermal methods have been successfully explored to fabricate various kinds of nanostructured vanadium oxides and their derived compounds. ${ }^{27-29}$ In this paper, we use a simple method for the synthesis of various submicronic particles vanadium oxides with valence state controlled.

The electrochromic performance of vanadium oxide depends on several parameters including film thickness, morphology and porosity and the deposition method. Various physical and chemical techniques such as, thermal evaporation, electron beam evaporation, magnetron sputtering, sol-gel, electrochemical deposition and pulsed laser ablation have been used for the deposition of vanadium oxide films. ${ }^{30-32}$ Among several deposition techniques, Doctor Blading presents the advantage of high versatility, low cost, reasonable deposition rates and simplicity in experimental parameters modulation.

In this work, based on our recent study, ${ }^{33}$ we report a robust synthetic methodology that provides access to stoichiometrycontrol of the final films $\left(\mathrm{V}_{2} \mathrm{O}_{5}\right.$ or $\left.\mathrm{V}_{2} \mathrm{O}_{3}\right)$. The polyol route used to synthesize the pure vanadium oxides is low cost and easy transferable in large scale production.

In a second part, the electrochromic properties of the Doctor Blading $\mathrm{V}_{2} \mathrm{O}_{3}$ and $\mathrm{V}_{2} \mathrm{O}_{5}$ thick films are characterized by cyclic voltammetry in ionic liquid combined with in-situ optical measurements and ex-situ XRD after cycling, and compared. Several redox steps are observed and discussed, which gives rise to a variety of color transitions as a function of the applied voltage. Moreover, the optical properties of the vanadium oxide films assigned to the different oxidation-reduction steps upon electrochemical cycling are characterized by ex-situ X-ray photoelectron spectroscopy measurements.

Finally, consisting of the main discovery issued from these studies, the very surprising similarities of the electrochromic behaviors of $\mathrm{V}_{2} \mathrm{O}_{3}$ and $\mathrm{V}_{2} \mathrm{O}_{5}$ raw films will be analyzed and deeply discussed thanks to grazing incidence $\mathrm{X}$-ray diffraction.

\section{RESULTS AND DISCUSSION}

II.1. Characterization of $\mathrm{V}_{2} \mathrm{O}_{3}$ and $\mathrm{V}_{2} \mathrm{O}_{5}$ powders

The XRD patterns of the $\mathrm{V}_{2} \mathrm{O}_{3}$ and $\mathrm{V}_{2} \mathrm{O}_{5}$ powders synthesized by the polyol process as described in the experimental section (IV) and supporting information, are shown in Figure 1. It is obvious that the crystalline phases for vanadium oxides are discriminatory depending on the gas nature used in the thermal treatment, either $\mathrm{Ar} / \mathrm{H}_{2}$ for $\mathrm{V}_{2} \mathrm{O}_{3}$ or air for $\mathrm{V}_{2} \mathrm{O}_{5}$. No secondary phases are found in these patterns, and the sharpness of the diffraction peaks highlights the highly crystalline nature of the powders. Indeed, the diffraction pattern of the powder annealed under $95 \% \mathrm{Ar} / 5 \% \mathrm{H}_{2}$ gas mixture (Figure 1a), shows the presence of narrow peaks, suggesting a material with high crystallinity. The d-spacing values of all diffraction peaks are identical to those of the rhombohedral crystalline phase $\mathrm{V}_{2} \mathrm{O}_{3}$ with (00-034-0187 JCPDS data file; R-3c space group). No peak of any other phase or impurity was detected from the XRD pattern indicating that $\mathrm{V}_{2} \mathrm{O}_{3}$ with high purity can be synthesized via polyol synthesis at $160{ }^{\circ} \mathrm{C}$ for $1 \mathrm{~h}$ followed by an annealing at $500{ }^{\circ} \mathrm{C}$ under $95 \% \mathrm{Ar} / 5 \% \mathrm{H}_{2}$ gas mixture.

The X-ray pattern of the powder annealed under air (Figure 1b) shows that all the peaks are perfectly indexed to the orthorhombic $\mathrm{V}_{2} \mathrm{O}_{5}$ with Pmmn space group. All of the isolated phases are well-crystallized; nevertheless, despite the same temperatures and dwell times used for the annealing, the peak widths vary with the vanadium oxidation state: they increase as the valence state decreases.

To complete the structural studies, refinements using two models are compared: full-pattern matching using an isotropic peak profile function (Caglioti function) and full-pattern matching using an anisotropic peak profile function with a crystallographic direction corresponding to the (110) axis for both compounds. By comparison of the results obtained with the two full-pattern matching, the crystallite shapes are clearly anisotropic with an elongation along the (110) crystallographic axis. The use of an anisotropic model allows a significant decrease of the reliability factors $R_{p}, R_{w p}$, and $R_{\text {exp }}$. The unit cells and reliability factors of the anisotropic refinement for $\mathrm{V}_{2} \mathrm{O}_{3}$ and $\mathrm{V}_{2} \mathrm{O}_{5}$ are gathered in Table 1 .
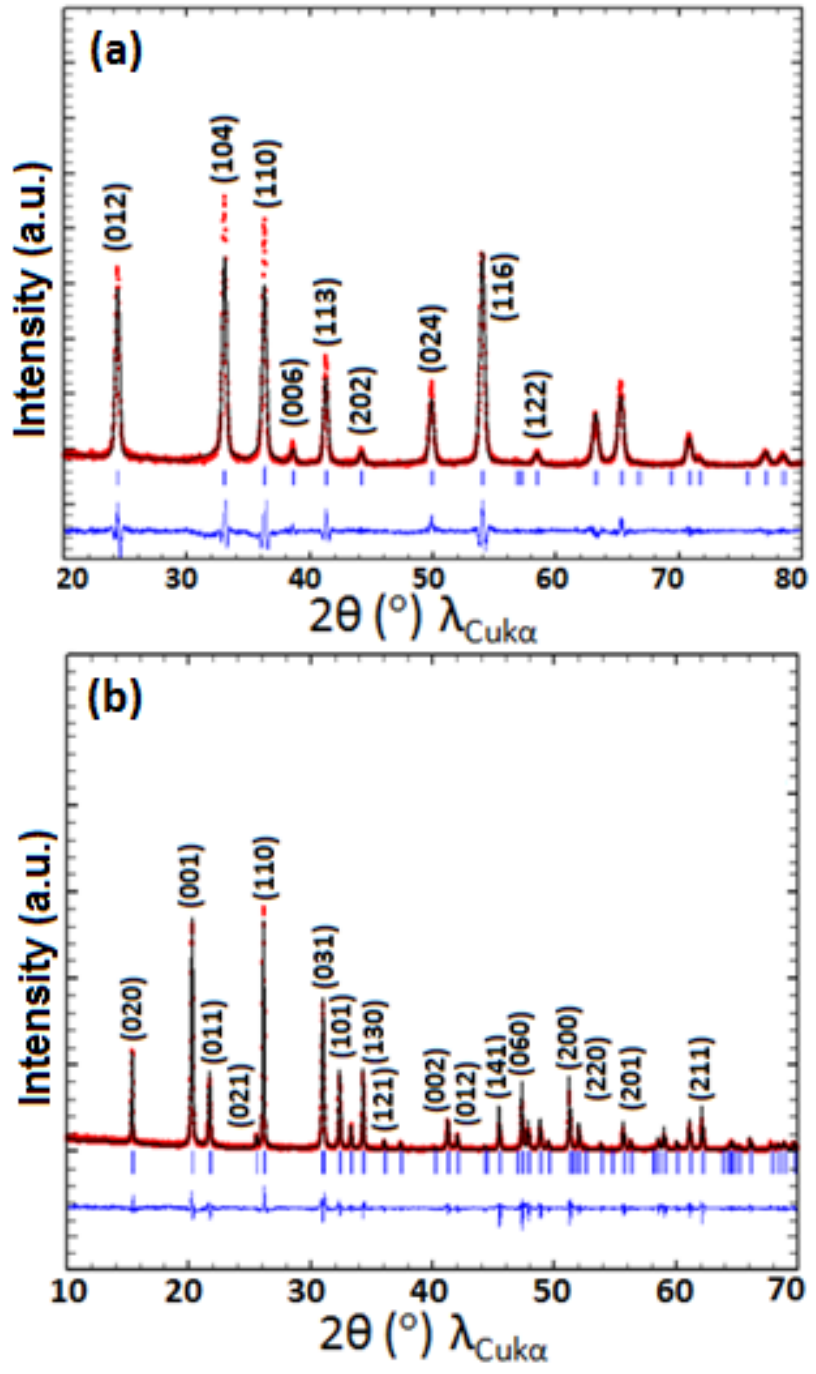

FIGURE 1. Full-pattern matching using an anisotropic peak profile of $\mathrm{V}_{2} \mathrm{O}_{3}$ (vanadium sesquioxide; $\mathrm{R} \overline{\mathrm{c}}$ space group) powders (a) and $\mathrm{V}_{2} \mathrm{O}_{5}$ (vanadium pentoxide; Pmmn space group) powders (b).

TABLE 1. Unit-cells parameters and R reliability factors extracted from the pattern matching refinement of $\mathrm{V}_{2} \mathrm{O}_{3}$ and $\mathrm{V}_{2} \mathrm{O}_{5}$ powders.
$a(\AA ̊)$
$b(\AA ̊)$
$c(\AA ̊)$
$R$ factors 


\begin{tabular}{|c|c|c|c|c|}
\hline $\mathbf{V}_{2} \mathbf{O}_{3}$ & $4.9517(3)$ & $=a$ & 13.999(1) & $\begin{aligned} \mathrm{R}_{\mathrm{p}} & =14.2 \\
\mathrm{R}_{\mathrm{wp}} & =19.8 \\
\mathrm{R}_{\exp } & =10.4\end{aligned}$ \\
\hline $\mathrm{V}_{2} \mathrm{O}_{5}$ & $11.5110(1)$ & $3.5640(2)$ & $4.3723(5)$ & $\begin{aligned} \mathrm{R}_{\mathrm{p}} & =14.6 \\
\mathrm{R}_{\mathrm{wp}} & =19.9 \\
\mathrm{R}_{\text {exp }} & =10.7\end{aligned}$ \\
\hline
\end{tabular}

SEM images show a drastic evolution of the morphology from the as-synthesized $\mathrm{V}_{2} \mathrm{O}_{3}$ to $\mathrm{V}_{2} \mathrm{O}_{5}$ powders while both consist of homogeneous particles (Figure 2). Quasi-spherical agglomerates with individual size of about $100 \mathrm{~nm}$ diameter are visible.
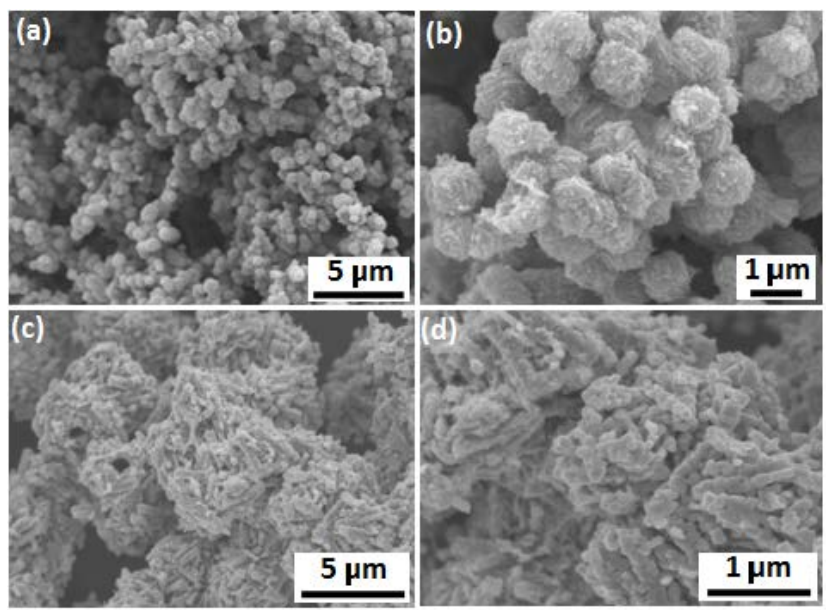

FIGURE 2. SEM Images of $\mathrm{V}_{2} \mathrm{O}_{3}(\mathrm{a}, \mathrm{b})$ and $\mathrm{V}_{2} \mathrm{O}_{5}$ (c, d) powders.

The TEM images (Figure 3) show that the oxides consist of submicronic crystallites aggregated in packs. In good agreement with the narrower diffraction peak widths (Figure 1b), the $\mathrm{V}_{2} \mathrm{O}_{5}$ crystallites exhibit larger diameter. The average crystallite diameter can be roughly estimated as $\sim 100-150 \mathrm{~nm}$ for $\mathrm{V}_{2} \mathrm{O}_{5}$ and decreases to about $30 \mathrm{~nm}$ for $\mathrm{V}_{2} \mathrm{O}_{3}$.

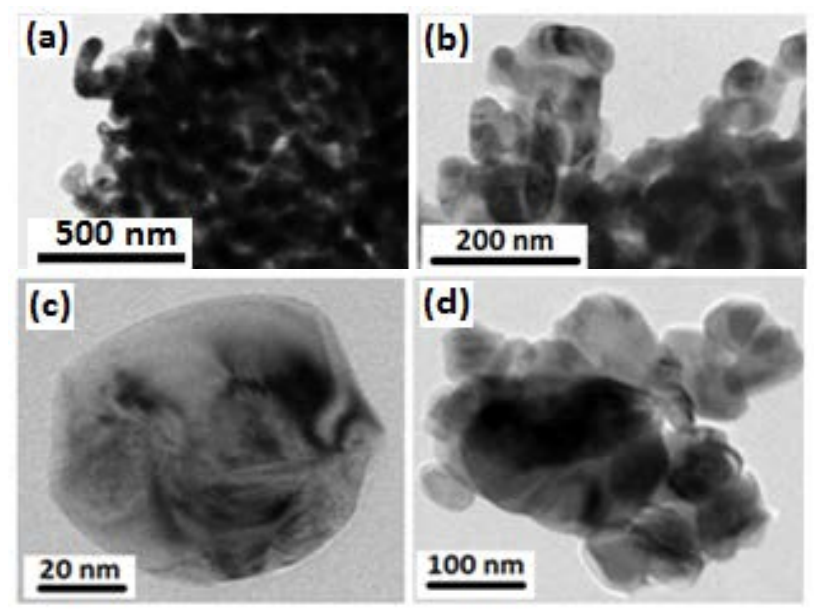

FIGURE 3. TEM Images of $\mathrm{V}_{2} \mathrm{O}_{3}(\mathrm{a}, \mathrm{b})$ and $\mathrm{V}_{2} \mathrm{O}_{5}$ (c, d) powders.

II.2. From $\mathrm{V}_{2} \mathrm{O}_{3}$ and $\mathrm{V}_{2} \mathrm{O}_{5}$ powders to thick films

The SEM top-surface images of $\mathrm{V}_{2} \mathrm{O}_{3}$ and $\mathrm{V}_{2} \mathrm{O}_{5}$ films are reported in Figure 4a and $\mathbf{4 b}$, respectively. The morphology of the $\mathrm{V}_{2} \mathrm{O}_{3}$ film is homogeneous, without any large aggregates or agglomerates. The XRD pattern of the as deposited $\mathrm{V}_{2} \mathrm{O}_{3}$ film is similar to the one of the powder (Figure S1); thus the crystallite size and shape of the $\mathrm{V}_{2} \mathrm{O}_{3}$ powder appear not modified by the film deposition Doctor Blading process. To support this assertion, it can be added that the $\mathrm{X}$-ray diffraction pattern of the $\mathrm{V}_{2} \mathrm{O}_{3}$ film can be refined using an isotropic peak profile function, leading to roughly the same parameters and peak profile as for the starting powder. On the contrary, a drastic evolution of the morphology from powder to film is observed for $\mathrm{V}_{2} \mathrm{O}_{5}$. It is obvious that the deposition method plays an important role in modifying the surface morphology of the vanadium oxide films. Indeed, the $\mathrm{V}_{2} \mathrm{O}_{5}$ film consists of platelets arranged parallel to the substrate (Figure 4b). For the $\mathrm{V}_{2} \mathrm{O}_{5}$ film, the $\mathrm{X}$-ray diffraction pattern (Figure 4c) reveals that the d-spacing values of the diffraction peaks match with the ones of the orthorhombic crystalline phase and the ones of the ITO sub-coating. A clear preferential orientation is shown. Indeed, the main peaks located at $2 \theta=20.2^{\circ}$ and $40.0^{\circ}$ corresponding to the (001) and (002) miller indexes, are of very large intensity, which indicates that the a-b plane of the film is parallel to the substrate (i.e. with c-axis as preferential orientation). From the X-ray pattern refinement using anisotropic peak profile function, the crystallite sizes along (001) and (hk0) directions are calculated of about $1.2 \mu \mathrm{m}$ and $20 \mathrm{~nm}$, respectively. The remarkable anisotropy of the $\mathrm{V}_{2} \mathrm{O}_{5}$ film's crystallites, may be due to surface dissolutionrecrystallization of the crystallites into the suspension before the Doctor-Blade coating. A phenomenon of surface dissolution-recrystallisation of the $\mathrm{V}_{2} \mathrm{O}_{5}$ particles into the asprepared inks for deposition involves that a change of stoichiometry between vanadium and oxygen must not be excluded, especially near the particles' surface.
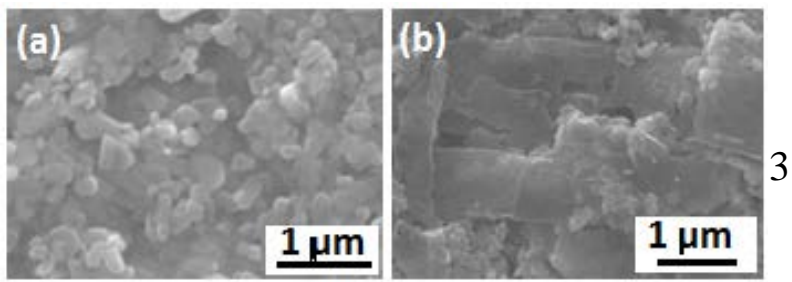


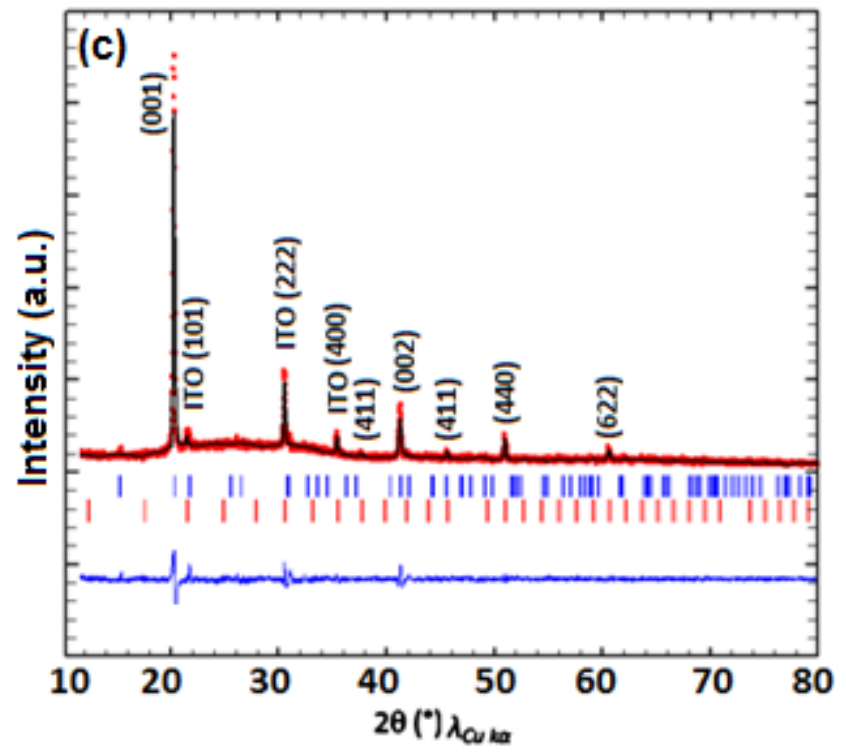

FIGURE 4. SEM images of $\mathrm{V}_{2} \mathrm{O}_{3}$ film (a) and $\mathrm{V}_{2} \mathrm{O}_{5}$ film (b); fullpattern matching using an anisotropic peak profile for $\mathrm{V}_{2} \mathrm{O}_{5}$ film (c) deposited by Doctor-Blade method.

II.3. Electrochromic properties of $\mathrm{V}_{2} \mathrm{O}_{3}$ and $\mathrm{V}_{2} \mathrm{O}_{5}$ films

The electrochemical stability is one of the key parameters to be taken into account when aiming at applications. Electrochemical properties of $\mathrm{V}_{2} \mathrm{O}_{3}$ and $\mathrm{V}_{2} \mathrm{O}_{5}$ films coated on ITO / glass substrate were evaluated for comparison by cyclic voltammograms (CV) followed by ex-situ optical measurements. As discussed below, the repetitive cycling of $\mathrm{V}_{2} \mathrm{O}_{3}$ and $\mathrm{V}_{2} \mathrm{O}_{5}$ thick film in ionic liquid (LiTFSI-EMITFSI) at a scan rate of $20 \mathrm{mV} / \mathrm{s}$ shows good cyclability and stability up to 500 cycles. It should be emphasized that to our knowledge such cyclability of $\mathrm{V}_{2} \mathrm{O}_{3}$ thick films has not been reported in the literature yet.

Figure 5a displays the $1^{\text {st }}, 5^{\text {th }}$ and $500^{\text {th }} \mathrm{CV}$ of $\mathrm{V}_{2} \mathrm{O}_{3}$ film cycled in ITO/ $\mathrm{V}_{2} \mathrm{O}_{3} /$ LiTFSI-EMITFSI/Pt vs SCE cells started in oxidation. The small capacity of the first oxidation is rapidly followed by a reversible cycling. Upon reduction, the voltammograms show a large current wave, constituted of two main peaks located at $0.45 \mathrm{~V}$ and $-0.47 \mathrm{~V}$ while in oxidation, two main peaks located at $0.51 \mathrm{~V}$ and $0.93 \mathrm{~V}$ are visible. The reversibility of the process is illustrated by a Coulombic efficiency defined as a $\mathrm{Q}_{\mathrm{red}} / \mathrm{Q}_{\mathrm{ox}}$ ratio keeping close to $100 \%$ (Figure S2a), while a slight increase in capacity is observed with cycling. The colors reached by the films at different voltages measured by diffuse reflectance in the range of 400 $800 \mathrm{~nm}$ are presented in Figure 5b. The $\mathrm{V}_{2} \mathrm{O}_{3}$ films switch reversibly in-between a reduced blue state $(-0.9 \mathrm{~V})$ and an oxidized-orange state $(+1.9 \mathrm{~V})$ associated with reflectance values less than $5 \%$ and of $35 \%$ at $600 \mathrm{~nm}$, respectively, leading to an optical reflectance modulation, $\Delta \mathrm{R}$, of about $30 \%$.
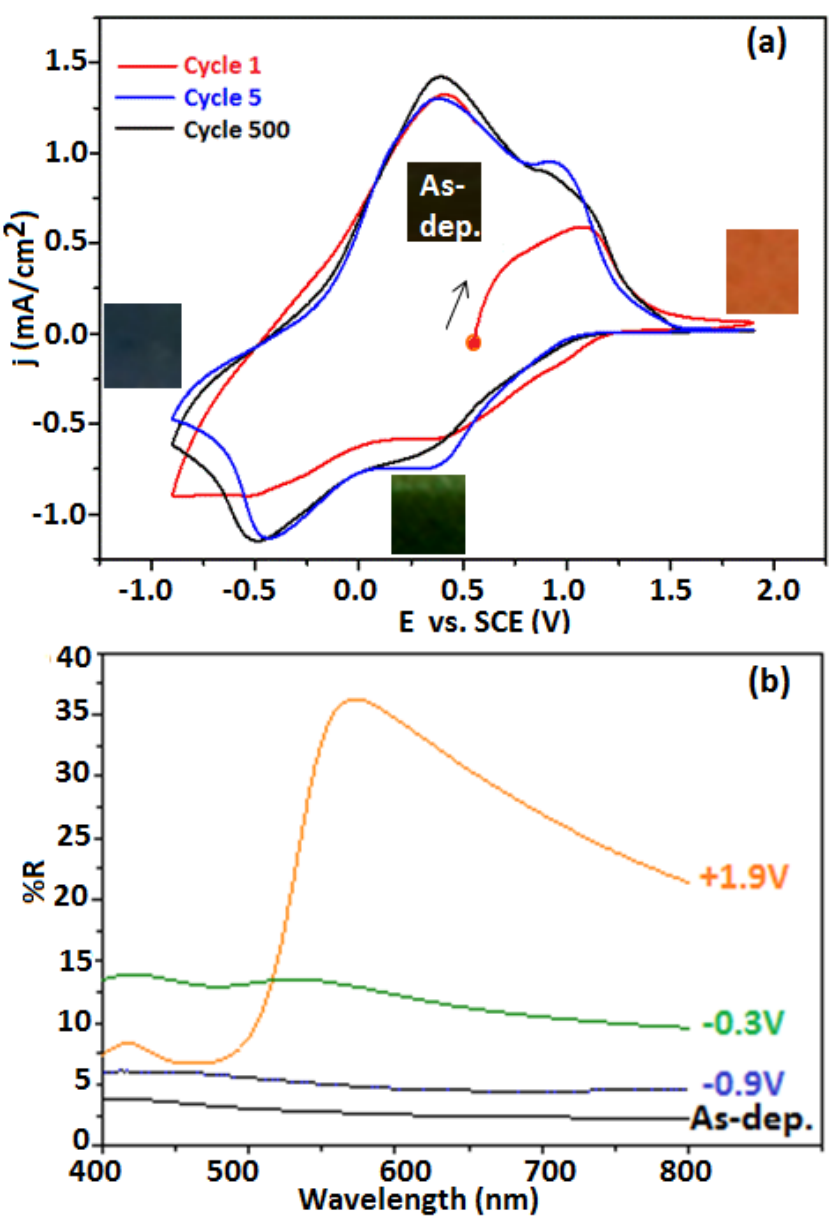

FIGURE 5. Cyclic voltammograms for $\mathrm{V}_{2} \mathrm{O}_{3}$ film cycled in ITO/ $\mathrm{V}_{2} \mathrm{O}_{3} / \mathrm{LiTFSI-EMITFSI/Pt}$ vs SCE (a). ex-situ diffuse reflectance spectra of the $\mathrm{V}_{2} \mathrm{O}_{3}$ films at various potentials at $50^{\text {th }}$ cycle : black initial state (as-deposited), oxidized orange state $(+1.9 \mathrm{~V})$, reduced green state $(-0.3 \mathrm{~V})$ and more reduced blue state $(-0.9 \mathrm{~V})(\mathrm{b})$.

In CIE colorimetric space, the color is represented by three parameters, the luminance axis $\left(\mathrm{L}^{*}\right)$ and two hue axes $\left(\mathrm{a}^{*}\right)$ and (b*), which can be used to define and compare quantitatively the colors. The relative luminance $\left(\mathrm{L}^{*}\right)$, the hue $\left(\mathrm{a}^{*}\right)$ and $\left(\mathrm{b}^{*}\right)$ values of $\mathrm{V}_{2} \mathrm{O}_{3}$ films in different states were calculated from the reflectance spectra. For the light blue-reduced state (at $-0.9 \mathrm{~V}$ ), the $L^{*} a * b *$ parameters are $26,-15$, and -6 , respectively, while for the bright orange-oxidized state (at $+1.9 \mathrm{~V}$ ) the $\mathrm{L}^{*} \mathrm{a}^{*} \mathrm{~b}^{*}$ parameters are 68,11 and 56 , respectively. The contrast $\Delta \mathrm{E}^{*}=$ $\left[\left(\mathrm{L}_{2}-\mathrm{L} *_{1}\right)^{2}+\left(\mathrm{a} *_{2}-\mathrm{a}_{1}\right)^{2}+\left(\mathrm{b} *_{2}-\mathrm{b} *_{1}\right)^{2}\right]^{1 / 2}$ is of 79 .

The repetitive cycling of $\mathrm{V}_{2} \mathrm{O}_{5}$ films using similar conditions shows also good cyclability and stability in terms of capacity up to 500 cycles (Figure 6a). CVs of $\mathrm{V}_{2} \mathrm{O}_{5}$ film cycled in ITO/ $\mathrm{V}_{2} \mathrm{O}_{5} /$ LiTFSI-EMITFSI/Pt vs SCE cells exhibit a large redox current wave constituted of different convoluted peaks, during both the positive and cathodic scans, however slightly shifted to higher potential values as compared to the ones of

$\mathrm{V}_{2} \mathrm{O}_{3}$. Furthermore, as for $\mathrm{V}_{2} \mathrm{O}_{3}$ films, and in agreement with a clear reversible process, the charges deduced from $\mathrm{V}_{2} \mathrm{O}_{5}$ cyclic 
voltammetric measurements in reduction and in oxidation are equal $\left(\mathrm{Q}_{\mathrm{red}} / \mathrm{Q}_{\mathrm{ox}}=99 \%\right)$ whatever the cycle number. Upon cycling the capacity significantly increases, of about $10 \%$ in between the very first cycles and the $500^{\text {th }}$ cycle (Figure S2b). In respect to the optical behavior, the lithium insertion/ deinsertion process is accompanied by a clear three-step electrochromism, deep blue $\rightleftarrows$ green $\rightleftarrows$ orange. The $\mathrm{V}_{2} \mathrm{O}_{5}$ films switch reversibly in-between a reduced blue state $(-0.9 \mathrm{~V})$ and an oxidized-orange state $(+1.9 \mathrm{~V})$ associated with reflectance values of about $5 \%$ and $55 \%$ at $600 \mathrm{~nm}$, respectively, leading to an optical reflectance modulation, $\Delta \mathrm{R}$, of about $50 \%$ (Figure 6b). For the blue, reduced state (at $-0.9 \mathrm{~V}$ ), the calculated $\mathrm{L}^{*} \mathrm{a} * \mathrm{~b} *$ parameters are $31,-14$, and -9 , respectively, while for the orange, oxidized state (at $+1.9 \mathrm{~V}$ ) the $\mathrm{L}^{*} \mathrm{a} * \mathrm{~b} *$ parameters are 71,12 and 48, respectively. The contrast $\Delta \mathrm{E}^{*}$ is of 74 . Interestingly, if similar $\Delta \mathrm{E}^{*}$ contrast values, of about 75 to 80 $\%$ are recorded for both oxides, the higher electrochemical capacity associated with this orange to blue transition for the $\mathrm{V}_{2} \mathrm{O}_{3}$ thick film as compared to the $\mathrm{V}_{2} \mathrm{O}_{5}$ one emphasized its good EC properties. Commonly evaluated by the color efficiency, CE, for transmisttive systems (i.e. CE = 1/Q log $\left(T_{b} / T_{c}\right)$ where $Q$ is the electrochemical capacity, Tb and Tc the transmittance in the bleached and colored state). In the case of thick films, the modulation of $\Delta \mathrm{E}^{*}$ vs $\mathrm{Q}$ may be indeed considered as a criteria of merit in favor of $\mathrm{V}_{2} \mathrm{O}_{3}$. In addition, the evaluation of the switching times from chronoamperometry measurements confirms the slightly higher properties of $\mathrm{V}_{2} \mathrm{O}_{3}$. Both oxides exhibit switching times of few seconds in between orange $(+1.9 \mathrm{~V})$ to blue $(-0.9 \mathrm{~V})$ colors, namely 7s (oxidized orange) and $5 \mathrm{~s}$ (reduced blue) for $\mathrm{V}_{2} \mathrm{O}_{3}$ and $9 \mathrm{~s}$ (oxidized orange) $6 \mathrm{~s}$ (reduced blue) for $\mathrm{V}_{2} \mathrm{O}_{5}$.
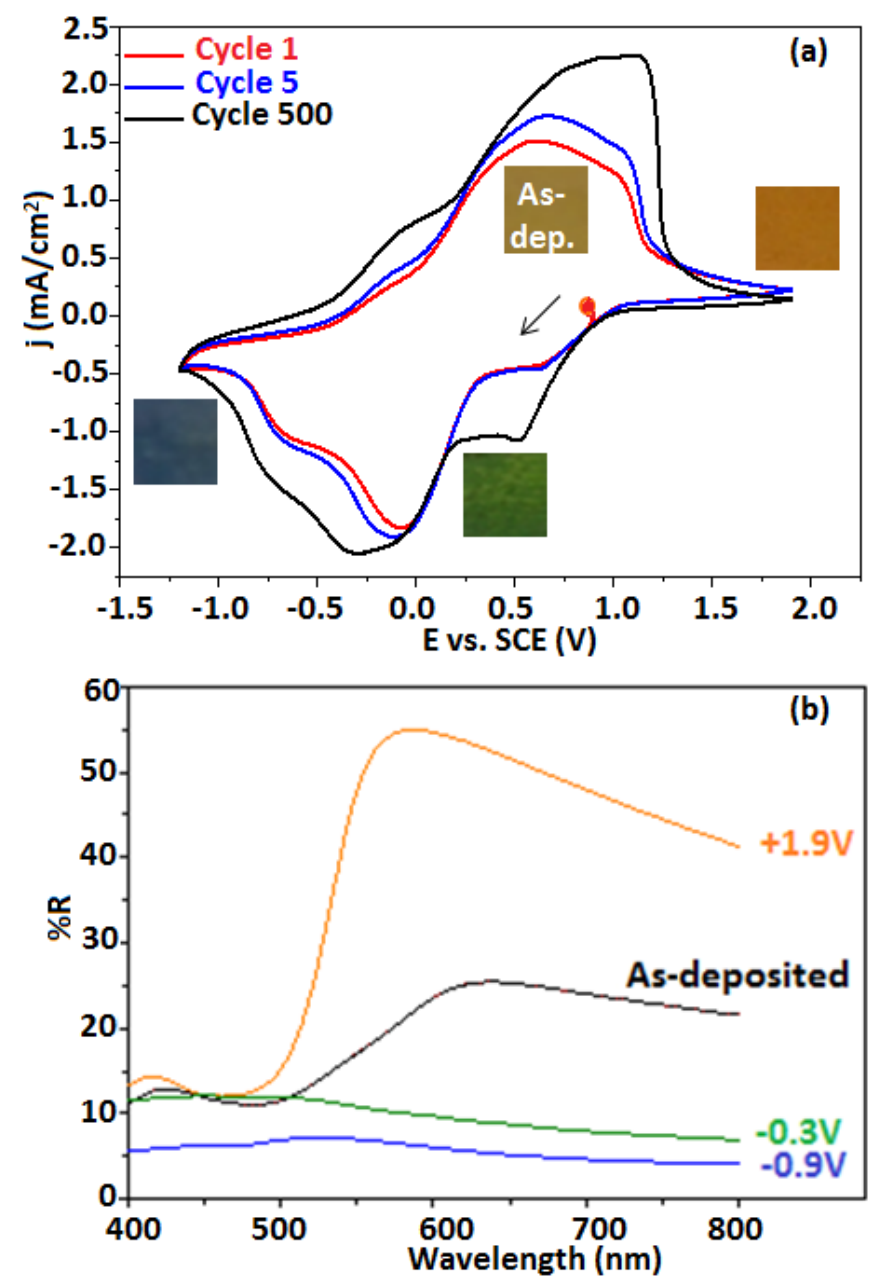

FIGURE 6. Cyclic voltammograms for $\mathrm{V}_{2} \mathrm{O}_{5}$ film cycled in ITO/ $\mathrm{V}_{2} \mathrm{O}_{5} / \mathrm{LiTFSI}-E M I T F S I / P t$ vs SCE (a). ex situ diffuse reflectance spectra of the $\mathrm{V}_{2} \mathrm{O}_{5}$ films at various potentials at $50^{\text {th }}$ cycle : initial state (as-deposited), oxidized orange state $(+1.9 \mathrm{~V})$, reduced green state $(-0.3 \mathrm{~V})$ and more reduced blue state $(-0.9 \mathrm{~V})$ (b).

The memory effect, namely persistence of the colored state after the voltage being cut, is a key characteristic of electrochromic materials. In this work, both oxides show good memory effect after long times (30 days). All the films in different states (blue and orange) for both oxides were exposed in air at room temperature, and the stability of the films was tested after 30 days with no electrical voltage applied. To illustrate this stability, the $\mathrm{L}^{*} \mathrm{a} * \mathrm{~b}$ parameters for blue-reduced state $(-0.9 \mathrm{~V})$ and orange oxidized state $(+1.9 \mathrm{~V})$ in initial state and after 30 days were determined and are summarized in Table S1 and Table S2. The analysis of the $\mathrm{L}^{*} \mathrm{a} * \mathrm{~b}$ parameters for both oxides at the initial state and after one month shows that there is no change in chromaticity parameters after 30 days. This demonstrates that $\mathrm{V}_{2} \mathrm{O}_{3}$ and $\mathrm{V}_{2} \mathrm{O}_{5}$ films possess great electrochromic color memory properties with excellent color stability at the oxidized/reduced state. Their good electrochromic color memory properties may be ascribed to the intrinsic stability and their porosity of Doctor Blading $\mathrm{V}_{2} \mathrm{O}_{3}$ and $\mathrm{V}_{2} \mathrm{O}_{5}$ films that help the electrolyte ions insertion/deinsertion 
into the film to stabilize the reduced and oxidized state by Coulomb force.

The close EC behavior for both $\mathrm{V}_{2} \mathrm{O}_{3}$ and $\mathrm{V}_{2} \mathrm{O}_{5}$ films, exhibiting different morphologies, structures and compositions (i.e. different vanadium oxidation states) raises the question of the mechanism at the origin of the multichromism.

\section{II.4. Mechanism}

From what is generally accepted in $\mathrm{V}_{2} \mathrm{O}_{5}, \mathrm{Li}$ insertion and deinsertion takes place following the $\mathrm{V}_{2} \mathrm{O}_{5}+\mathrm{xLi}^{+}+\mathrm{xe}^{-}=$ $\mathrm{Li}_{\mathrm{x}} \mathrm{V}_{2} \mathrm{O}_{5}$ reaction. Thus upon reduction the simultaneous injection of electrons and $\mathrm{Li}^{+}$ions into the $\mathrm{V}_{2} \mathrm{O}_{5}$ film leads to a progressive reduction of pentavalent vanadium $\left(\mathrm{V}^{5+}\right)$ to its lower valence state $\left(\mathrm{V}^{4+}\right)$ and eventually to $\left(\mathrm{V}^{3+}\right)^{34}$. In oxidation, the extraction of electrons and $\mathrm{Li}^{+}$ions from $\mathrm{Li}_{\mathrm{x}} \mathrm{V}_{2} \mathrm{O}_{5}$ film leads to the oxidation of lower valence vanadium $\left(\mathrm{V}^{4+}\right.$ or $\left.\mathrm{V}^{3+}\right)$ to its pentavalent state $\left(\mathrm{V}^{5+}\right)$.

The number of exchanged electrons (x) involved during each coloration/bleaching process was estimated using the following equation: ${ }^{13} \mathrm{Q}=\mathrm{F}^{*} \mathrm{nV}_{2} \mathrm{O}_{5} * \mathrm{x}$, where $\mathrm{Q}$ is the electrochemical capacity, $\mathrm{F}=96500 \mathrm{C}$, and $\mathrm{n}$ is number of moles, assuming a density of $75 \%$. The $x$ values calculated from $\mathrm{V}_{2} \mathrm{O}_{5}$ films is about 1.1. The number of exchanged electrons remains much lower than to the expected one if $\mathrm{V}^{5+}$ ions are fully reduced to $\mathrm{V}^{4+}$ or even $\mathrm{V}^{3+}$ ions.

The electrochemical behaviors of $\mathrm{V}_{2} \mathrm{O}_{5}$ and $\mathrm{V}_{2} \mathrm{O}_{3}$ films do not appear as different as it could be expected. The oxidation of $\mathrm{V}_{2} \mathrm{O}_{3}$ during the first half cycle can only be explained by oxygen anion sources. Nonetheless, the electrochromic behavior of $\mathrm{V}_{2} \mathrm{O}_{3}$, on the point of view of the change of colorations, is similar to other reports of other vanadium oxides with a threestep mechanism implying a blue to green color first change and then a green to orange color change (in oxidation scan).

The multi-step electrochromism from orange to green and green to blue, during the reduction of $\mathrm{V}_{2} \mathrm{O}_{5}$ films (with reverse phenomenon during oxidation) was previously observed by several authors. ${ }^{34-37}$ It can be associated, as we proposed here, to a double oxidation number change $\left(\mathrm{V}^{5+}\right.$ to $\mathrm{V}^{4+}$ and then $\mathrm{V}^{4+}$ to $\mathrm{V}^{3+}$ ). In this way, Tong et al. ${ }^{34}$ recently ascribed the color change to olive green to the presence of $\mathrm{V}^{3+}$ ions, associating the multiple colors in $\mathrm{V}_{2} \mathrm{O}_{5}$ to the presence of $\mathrm{V}^{3+} / \mathrm{V}^{4+}$ and $\mathrm{V}^{5+}$. Such observations well agree with the color of $\mathrm{V}^{3+}, \mathrm{V}^{4+}$, and $\mathrm{V}^{5+}$ in aqueous solutions: i.e., in an octahedral ligand field with aqua ligands. In the meantime, current investigations in our group on $\mathrm{V}_{2} \mathrm{O}_{5}$ thin films grown by RF sputtering confirm similar color changes of orange to green and green to blue upon cycling while only $1.5 \mathrm{Li}$ are being exchanged with the single presence of $\mathrm{V}^{5+}$ and $\mathrm{V}^{4+}$. In addition, similar multicolor electrochromism has been detected on amorphous $\mathrm{VO}_{\mathrm{x}}$ films, with $\mathrm{x}$ between 1.5 and 2. Nonetheless some authors ${ }^{38-40}$ have shown that the occurrence of a single $\mathrm{V}^{5+} / \mathrm{V}^{4+}$ redox couple, can explain the green intermediate coloration by a potential range where the vanadium ions with the two oxidation numbers coexist with a well-defined ratio. Also, the electrochemical capacities we have measured, close to 1 electron only per cycle, tend to show that (i) a redox process with only oxidation numbers involving a change of only one unit occurs, or (ii) only a fraction of about $25 \%$ of the film is submitted to the redox process. To study, in our case, the oxidation number really implied in the color changes observed in both $\mathrm{V}_{2} \mathrm{O}_{3}$ and $\mathrm{V}_{2} \mathrm{O}_{5}$ films, i.e to investigate what are the different amount mixtures of $\mathrm{V}^{5+}, \mathrm{V}^{4+}$, and $\mathrm{V}^{3+}$ ions, during cycling, ex-situ XPS spectroscopy, for different applied voltages, was performed. The V2 $\mathrm{p}_{3 / 2}$ core peak spectra of the film in different potential states corresponding to the distinct colorations: for the as-prepared films, the orange state (oxidized state after 50 cycles), the green (intermediate state after 50 cycles) and the blue one (reduced state after 50 cycles), reached during electrochromic recording were analyzed (Figures 7 and 8), and the corresponding fitting results are shown in Table 2 , for both $\mathrm{V}_{2} \mathrm{O}_{3}$ and $\mathrm{V}_{2} \mathrm{O}_{5}$ films.
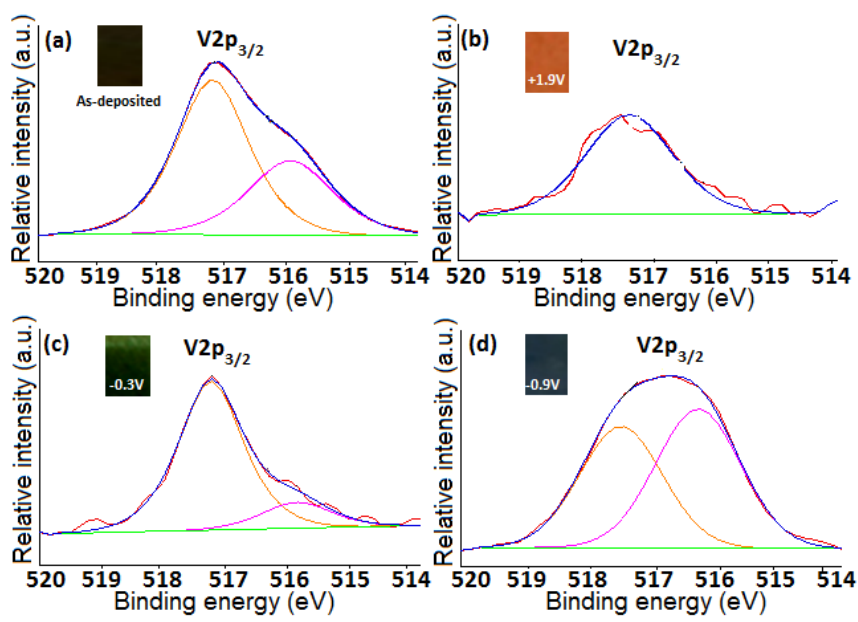

FIGURE 7. ex-situ XPS of $\mathrm{V}_{2} \mathrm{O}_{3}$ film before cycling (a) and after 50 cycles at oxidized state (b) reduced green state (c) and reduced blue state (d).
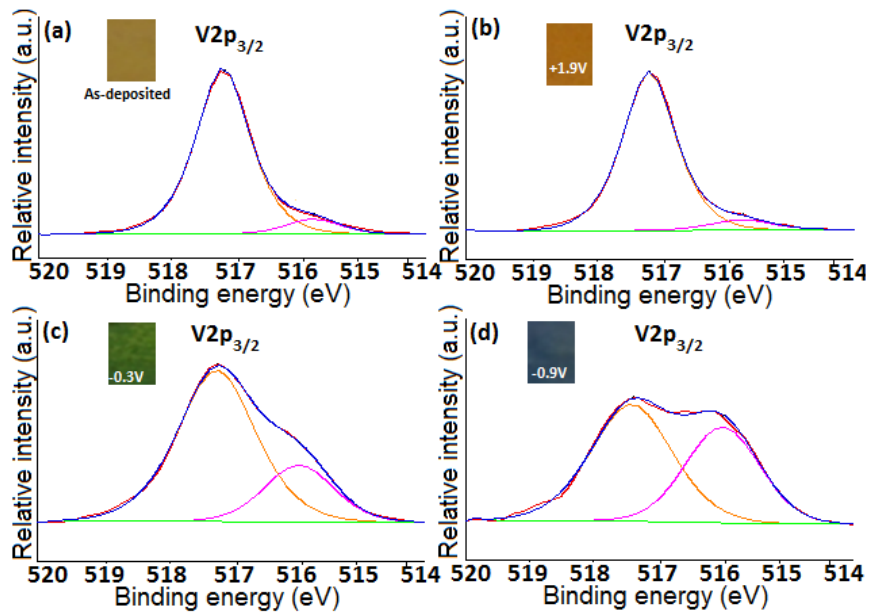

FIGURE 8. ex situ XPS of $\mathrm{V}_{2} \mathrm{O}_{5}$ film before cycling (a) and after 50 cycles at oxidized state (b) reduced green state (c) and reduced blue state (d).

In the potential range from $+1.9 \mathrm{~V}$ to $-0.9 \mathrm{~V}$, only two $\mathrm{V} 2 \mathrm{p}_{3 / 2}$ core peaks are identified. The orange coloration being associated with the occurrence of a very main peak near 517.5 $\mathrm{eV}$, this peak can be without any ambiguities ascribed to the $\mathrm{V}^{5+}$ ion. ${ }^{41}$ The second peak centered on $516 \mathrm{eV}$ is, based on literature on the previous $\mathrm{VO}_{\mathrm{x}}$ measurements, ascribed to the $\mathrm{V}^{4+}$ ions. $^{42}$ But, this last attribution can be contested and possibly, this peak is the convolution of the signals characteristic of both $\mathrm{V}^{3+}$ and $\mathrm{V}^{4+}$ ions. Indeed, it can be noted 
that none occurrence of a distinguishable $\mathrm{V}^{3+}$ peak for the $\mathrm{V}_{2} \mathrm{O}_{3}$ as-prepared film is surprising. On the other hand, and interestingly, $\mathrm{V}^{4+}$ ions which are detected in the as-prepared film may be derived from the partial dissolution of the $\mathrm{V}_{2} \mathrm{O}_{5}$ film which was strongly suggested by the observation of a change of the crystallite morphology between the film's crystallites and the powder ones, as previously discussed. The existence of $\mathrm{V}^{4+}$ in the as-prepared film also explains the observed "brownish" coloration of the as-prepared film in comparison with the brilliant orange color reached in oxidative regime.

Anyway, it can be supposed that the oxidation numbers measured from XPS spectroscopy are not fully representative of the oxidation numbers in the film's bulk. Surface redox processes may occurr before the analysis. So, the attribution of the detected peak to the $\mathrm{V}^{5+}$ and $\mathrm{V}^{4+}$ ions as representative of our film composition cannot be made without uncertainties.

TABLE 2. $\mathrm{V}^{5+}$ and $\mathrm{V}^{4+}$ quantification deduced from ex-situ XPS study after 50 cycles (100\% corresponds to normalization of the strongest contribution).

\begin{tabular}{|c|c|c|c|}
\hline $\mathrm{V}_{2} \mathrm{O}_{3}$ films & $\mathrm{V}^{5+}(\%)$ & $\mathrm{V}^{4+}(\%)$ & $\mathbf{R}=\mathbf{V}^{5+} / \mathbf{V}^{4+}$ \\
\hline As-deposited (Black) & 100 & 48 & 2.1 \\
\hline Green color (-0.3V) & 100 & 17 & 5.2 \\
\hline Blue color $(-0.9 \mathrm{~V})$ & 87 & 100 & 0.9 \\
\hline Orange color $(+1.9 \mathrm{~V})$ & 100 & nearly 0 & - \\
\hline $\mathrm{V}_{2} \mathrm{O}_{5}$ films & $\mathrm{V}^{5+}(\%)$ & $\mathrm{V}^{4+}(\%)$ & $\mathbf{R}=\mathbf{V}^{5+} / \mathbf{V}^{4+}$ \\
\hline As-deposited (Brown) & 100 & 9 & 11.1 \\
\hline Green color $(-0.3 \mathrm{~V})$ & 100 & 32 & 3.1 \\
\hline Blue color $(-0.9 \mathrm{~V})$ & 100 & 73 & 1.4 \\
\hline Orange color $(+1.9 \mathrm{~V})$ & 100 & 7 & 13.8 \\
\hline
\end{tabular}

Whatever, the difficulty to ascribe the different XPS core peaks to well-defined oxidation states, the evolution during cycling of the two different compositions studied and their comparison put into evidence remarkable similarities. The $\mathrm{R}=\mathrm{V}^{5+} / \mathrm{V}^{4+}$ ratios evolve quite similarly versus the applied potential for both $\mathrm{V}_{2} \mathrm{O}_{3}$ and $\mathrm{V}_{2} \mathrm{O}_{5}$ films. For a green coloration at $-0.3 \mathrm{~V}$, the $\mathrm{V}^{5+} / \mathrm{V}^{4+}$ ratio is in favor of the $\mathrm{V}^{5+}$ ion, but with a significant minor peak of $\mathrm{V}^{4+}$ signal; whereas this ratio is roughly around the unit, i.e. showing an equilibrate partition between $\mathrm{V}^{5+}$ and $\mathrm{V}^{4+}$ ions, when the blue color is obtained at $0.9 \mathrm{~V}$. For the return sweep, in oxidative regime at $1.9 \mathrm{~V}$, leading to an orange color, it is found that the $\mathrm{V}^{5+}$ ions are at the origin of nearly the whole XPS signal. From the ex-situ XPS analysis it seems that the multi-electrochromism showed in our $\mathrm{V}_{\mathrm{x}} \mathrm{O}_{\mathrm{y}}$ films, whatever the starting chemical composition, is due to switches between the vanadium states +4 and +5 . Especially, and without any ambiguities on this important suggestion, the oxidation of the vanadium oxide films, whatever their initial composition/structure, leads to a complete vanadium oxidation, it means that a pure $\mathrm{V}_{2} \mathrm{O}_{5}$ orange compound is reached.

To confirm the most significant result obtained by XPS, that is the complete oxidation of the vanadium species to oxidation state equal to 5 while an oxidative potential of $1.9 \mathrm{~V}$ is applied, starting from $\mathrm{V}_{2} \mathrm{O}_{5}$ as well as $\mathrm{V}_{2} \mathrm{O}_{3}$ film composition, X-ray analyses were performed (Figures 9 and 10).

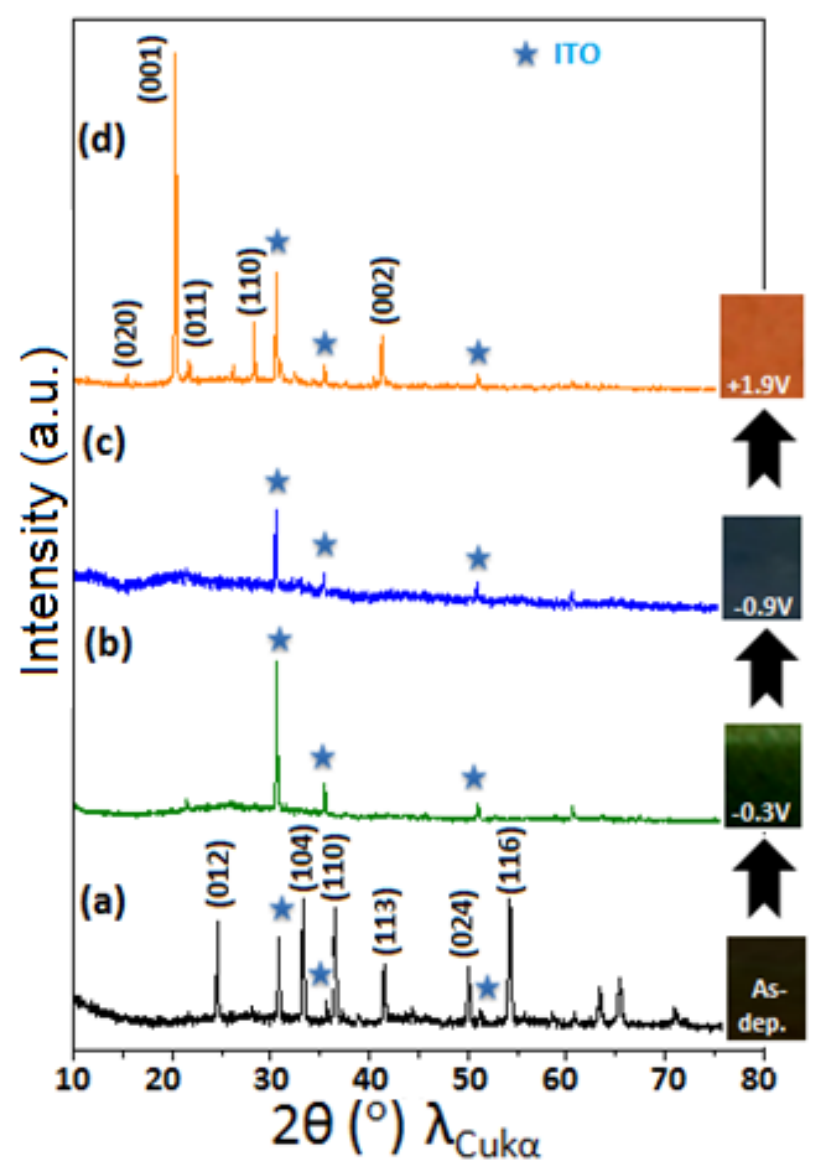

FIGURE 9. ex-situ Grazing incidence XRD of $\mathrm{V}_{2} \mathrm{O}_{3}$ film before cycling (a) and after 50 cycles at oxidized state (b) reduced green state (c) and reduced blue state (d). 


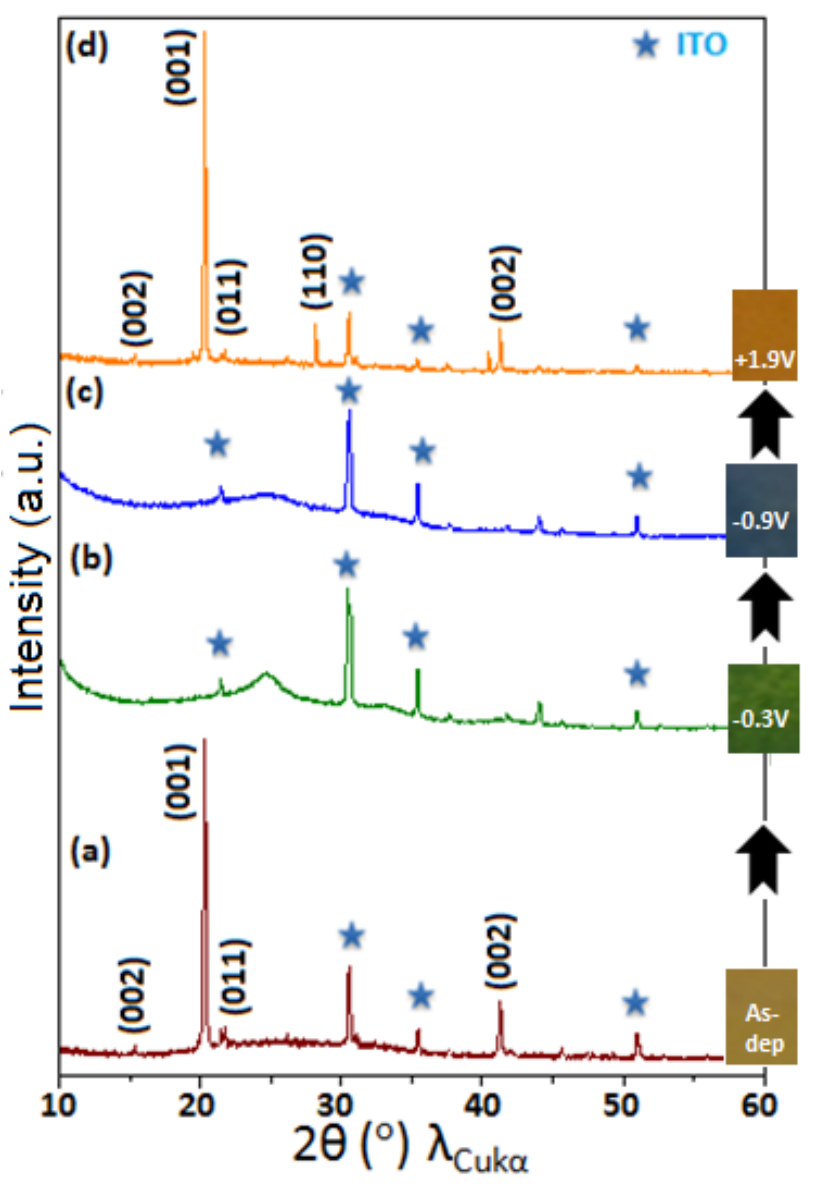

FIGURE 10. ex-situ Grazing Incidence XRD of $\mathrm{V}_{2} \mathrm{O}_{5}$ film before cycling (a) and after 50 cycles at oxidized state (b) reduced green state (c) and reduced blue state (d).

The X-ray patterns were recorded with the same grazing incidence $\left(2^{\circ}\right)$ on both $\mathrm{V}_{2} \mathrm{O}_{3}$ and $\mathrm{V}_{2} \mathrm{O}_{5}$ films for the four states of coloration previously discussed: black or brown, respectively (as-deposited), green $(-0.3 \mathrm{~V})$, blue $(-0.9 \mathrm{~V})$ and orange $(+1.9 \mathrm{~V})$. The measurements were realized after 50 cycles.

In Figure 9, all the peaks of the as-deposited $\mathrm{V}_{2} \mathrm{O}_{3}$ with black coloration are perfectly indexed to $\mathrm{V}_{2} \mathrm{O}_{3}$ phase without any preferential orientation (Figure 9a); the X-ray pattern for the film and the powder (Figure 1a) can be superimposed. For the two potentials corresponding to the green and the blue colors (Figure 9b and 9c), one can note the absence of the characteristic peaks of any $\mathrm{VO}_{\mathrm{x}}$ phase: the film becomes amorphous; the peaks, which are observed, are due to the ITO sub-layer. In oxidative regime $(+1.9 \mathrm{~V})$ (Figure 9d), leading to an orange coloration, the additional peaks observed on the $\mathrm{X}$ ray pattern, besides the ITO's peaks, can be indexed as well crystallized orthorhombic $\mathrm{V}_{2} \mathrm{O}_{5}$ (SG: Pmmn).

In Figure 10, the $\mathrm{X}$-ray patterns show that for as-deposited $\mathrm{V}_{2} \mathrm{O}_{5}$ with brownish coloration, all the peaks are perfectly indexed to $\mathrm{V}_{2} \mathrm{O}_{5}$ phase with a preferential orientation along the c-axis while for the reduction (to green and blue colors), only the peaks associated with ITO are observed. As previously, well-crystallized $\mathrm{V}_{2} \mathrm{O}_{5}$ is reformed upon oxidation.

These results are in agreement with the ones obtained by XPS; especially, $\mathrm{V}_{2} \mathrm{O}_{5}$ single phase in oxidation is confirmed. Indeed, whatever the starting composition, the X-ray pattern for the re- oxidized film after 50 cycles reveals that all peaks are identified to the vanadium pentoxide with high crystallinity. From ex-situ XRD analysis, it can be concluded that during cycling vanadium oxides pass through amorphous state during the reduction and that this state should be characterized by a mixture of $\mathrm{V}^{4+}$ and $\mathrm{V}^{5+}$. During the return sweep, all the vanadium ions are fully oxidized into $\mathrm{V}^{5+}$ state, in agreement with the orange color. More surprisingly, the complete reoxidation, at the end of each cycle, allows each time the recrystallization of $\mathrm{V}_{2} \mathrm{O}_{5}$. Finally, the kinetic of the phenomenon was studied on the as-prepared $\mathrm{V}_{2} \mathrm{O}_{3}$ film, comparing the X-ray pattern recorded for an applied voltage of +1.9 V, after 5 cycles and 50 cycles (Figure S3). This comparison shows that even after 5 cycles, $\mathrm{V}_{2} \mathrm{O}_{5}$ single phase is already obtained. However, the strong preferential orientation of the film drastically increases between the $5^{\text {th }}$ and the $50^{\text {th }}$ cycle. This observation confirms a reorganization of the atomic matter all along the cycling processes, and can justify the slight coulombic efficiency increase observed for the $\mathrm{V}_{2} \mathrm{O}_{3}$ starting film with the number of cycles.

\section{CONCLUSION}

In this study, we show a robust scenario that provides access to stoichiometry-controlled and which leads to: (i) the synthesis of two oxides $\mathrm{V}_{2} \mathrm{O}_{3}$ and $\mathrm{V}_{2} \mathrm{O}_{5}$ from a single polyol route, (ii) the demonstration for the first time of the electrochromic properties of $\mathrm{V}_{2} \mathrm{O}_{3}$, (iii) a "multi-color" electrochromic behavior very similar while one compares $\mathrm{V}_{2} \mathrm{O}_{3}$ and $\mathrm{V}_{2} \mathrm{O}_{5}$ (i.e. independently of the starting stoichiometry), which is associated with an unusual recrystallization process of $\mathrm{V}_{2} \mathrm{O}_{5}$ in oxidative regime. The latter represents a great step forward for the understanding of the electrochromic properties of vanadium oxides. Moreover, it is also a progress in solid state chemistry since a new synthesis method for obtaining well-crystallized $\mathrm{V}_{2} \mathrm{O}_{5}$ films, with a strong preferential orientation, can be proposed from the oxidation of any $\mathrm{VO}_{\mathrm{x}}$ films.

\section{EXPERIMENTAL SECTION}

A detailed description of all the experimental procedures and techniques characterization is given in the supporting information (SI).

\section{ASSOCIATED CONTENT}

\section{Supporting Information}

The Supporting Information is available free of charge on the ACS Publications website at DOI:

It contains a detailed description of all the experimental procedures and techniques of characterization including the XRD of $\mathrm{V}_{2} \mathrm{O}_{3}$ powders and film, and ITO substrate and coulombic efficiency and its evolution during cycling for $\mathrm{V}_{2} \mathrm{O}_{3}$ and $\mathrm{V}_{2} \mathrm{O}_{5}$ films cycled in ITO/ $\mathrm{V}_{2} \mathrm{O}_{3}\left(\mathrm{~V}_{2} \mathrm{O}_{5}\right) / \mathrm{LiTFSI}-\mathrm{EMITFSI} / \mathrm{Pt}$ vs SCE cell. We also determine the $\mathrm{L}^{*} \mathrm{a}{ }^{*} \mathrm{*}$ parameters in the blue-reduced state and orange-oxidized state of $\mathrm{V}_{2} \mathrm{O}_{3}$ and $\mathrm{V}_{2} \mathrm{O}_{5}$ at initial state and after 30 days and also the ex-situ XRD of $\mathrm{V}_{2} \mathrm{O}_{3}$ film before cycling, after 5 cycles and 50 cycles in oxidized state. 


\section{AUTHOR INFORMATION}

\section{Corresponding Author}

*E-mail: aline.rougier@icmcb.cnrs.fr

\section{ORCID}

Issam Mjejri: 0000-0001-5313-3198

Manuel Gaudon : 0000-0002-6918-2004

Aline Rougier: 0000-0002-1340-734X

\section{Author Contributions}

The manuscript was written through contributions of all authors. All authors have given approval to the final version of the manuscript.

\section{Notes}

The authors declare no competing financial interest.

\section{REFERENCES}

(1) Li, Z. J. ; Shao, J. Y. ; Zhong, Y. W. Near-Infrared and TwoWavelength Electrochromism Based on Nanocrystalline $\mathrm{TiO}_{2}$ Films Functionalized with Ruthenium-Amine Conjugated Complexes. Inorg. Chem., 2017, 56, 8538-8546.

(2) Cai, G.; Wang, J.; Lee, P. S. Next-Generation Multifunctional Electrochromic Devices. Acc. Chem. Res. 2016, 49, 1469-1476.

(3) Yang, P.; Sun, Peng.; Mai, W. Electrochromic Energy Storage Devices. Mater., Today, 2016, 19, 394.

(4) Liu, Y.; Lv, Y.; Tang, Z.; He, L.; Liu, X. Highly Stable and Flexible ITO-Free Electrochromic Films with Bi-functional Stacked $\mathrm{MoO}_{3} / \mathrm{Ag} / \mathrm{MoO}_{3}$ Structures. Electrochim. Acta 2016, 189, 184-189.

(5) Papaefthimiou, S.; Leftheriotis, G.; Yianoulis, P. Advanced Electrochromic Devices Based on $\mathrm{WO}_{3}$ Thin Films. Electrochim. Acta 2001, 46, 2145-2150.

(6) Bucha, V. R.; Chawla, A. K.; Rawal, S. K.. Review on Electrochromic Property for $\mathrm{WO}_{3}$ Thin Films Using Different Deposition Techniques. Mater. Today: Proceedings 2016,3 , 1429-1437.

(7) Granqvist, C. G. Oxide electrochromics: An Introduction to Devices and Materials. Sol. Energy Mater. Sol. Cells, 2012, 99, 1-13.

(8) Dalavi, D. S.; Devan, R. S.; Patil, R. A.; Patil, R. S.; Ma, Y. R.; Sadale, S. B.; Kim, I.; Kim, J. H.; Patil, P. S. Efficient Electrochromic Performance of Nanoparticulate $\mathrm{WO}_{3}$ Thin Films. J. Mater. Chem. C, 2013, 1, 3722-3728.

(9) Chu, C. H.; Wu, H. W.; Huang, J. L. Novel $\mathrm{WO}_{3}$-Based Electrochromic Device for High Optical Modulation and Infrared Suppression. ieee electron device lett., 2015, 36, 256. (10) Danine, A.; Cojocaru, L.; Faure, C.; Olivier, C.; Toupance, T.; Campet, G.; Rougier, A. Room Temperature UV Treated $\mathrm{WO}_{3}$ Thin Films for Electrochromic Devices on Paper Substrate. Electrochim. Acta 2014, 129, 113-119.
(11) Beaujuge, P. M.; Ellinger, S.; Reynolds, J. R. The DonorAcceptor Approach Allows a Black-to-Transmissive Switching Polymeric Electrochrome. Nat., Mater., 2008, 7, 795-799.

(12) Mjejri, I.; Doherty, C. M.; Martinez, M. R.; Drisko, G.L.; Rougier, A. Double Sided Electrochromic Device Based on Metal-Organic Frameworks. ACS Appl. Mater. Interfaces 2017, 9, 39930.

(13) Mjejri, I.; Manceriu, L.M.; Gaudon, M.; Rougier, A.; Sediri, F. Nano-Vanadium Pentoxide Films for Electrochromic Displays. Solid State Ionics 2016, 292, 8-14.

(14) Talledo, A.; Granqvist, C. G. Electrochromic VanadiumPentoxide-Based Films: Structural, Electrochemical, and Optical Properties. J. Appl. Phys. 1995, 77, 4655.

(15) Cogan, S.F.; Nguyen, N. M.; Perrotti, S.J.; Rauh R. D. Optical Properties of Electrochromic Vanadium Pentoxide. J. Appl. Phys. 1989, 66, 1333.

(16) Kovendhan, M.; Joseph P. D.; Manimuthu, P.; Sendilkumar, A.; Karthick, S.N.; Sambasivam, S.; Vijayarangamuthu, K.; Kim, H. J.; Choi, B. C.; Asokan, K.; Venkateswaran, C.; Mohan R. Prototype Electrochromic Device and Dye Sensitized Solar Cell using Spray Deposited Undoped and ' $\mathrm{Li}$ ' Doped $\mathrm{V}_{2} \mathrm{O}_{5}$ Thin Film Electrodes. Curr. Appl. Physics, 2015, 15, 622-631.

(17) Lee, S.H.; Cheong, H.M.; Liu, P.; Tracy, C.E.; Pitts, J.R.; Deb, S. K. Improving the Durability of Ion Insertion Materials in a Liquid Electrolyte. Solid State Ionics 2003, 165, 81-87.

(18) Wang, B.Y.; Takahashi, K.; Lee, K.; Cao, G. Nanostructured Vanadium Oxide Electrodes for Enhanced Lithium-Ion Intercalation. Adv. Funct. Mater., 2006, 16, 11331144.

(19) Wang, Y.; Cao, G. $\mathrm{Li}^{+}$-Intercalation Electrochemical/Electrochromic Properties of Vanadium Pentoxide Films by Sol Electrophoretic Deposition. Electrochim. Acta 2006, 51, 4865-4872.

(20) Yao, J.; Li, Y.; Massé, R.C.; Uchaker, E.; Cao, G. Revitalized Interest in Vanadium Pentoxide as Cathode Materials for Lithium-ion Batteries and Beyond. Energy Storage Materials, 2018, 11, 205-259.

(21) Garcia-Lobato, M. A.; Martinez, A. I.; Perry, D. L.; Castro-Roman, M.; Zarate, R. A.; Escobar-Alarcon, L. Elucidation of the Electrochromic Mechanism of Nanostructured Iron Oxides Films. Sol Energy Mater. Sol. Cells 2011, 95, 751-758.

(22) Gonçalves, A.; Resende, J.; Marques, A.C.; Pinto, J.V.; Nunes, D.; Marie, A.; Goncalves, R.; Pereira, L.; Martins, R.; Fortunato, E. Smart Optically Active $\mathrm{VO}_{2}$ Nanostructured Layers Applied in Roof-Type Ceramic Tiles for Energy Efficiency. Sol. Energy. Mater. Sol. Cells 2016, 150, 1-9.

(23) Wu, C.; Feng, F.; Xie, Y. Design of Vanadium Oxide Structures with Controllable Electrical Properties for Energy Applications. Chem. Soc. Rev., 2013, 42, 5157-5183.

(24) Santulli, A. C.; Xu, W.; Parise, J. B.; Wu. L.; Aronson, M. C.; Zhang, F.; Nam, C. Y.; Black, C. T.; Tiano, A. L.; Wong, S. S. Synthesis and Characterization of $\mathrm{V}_{2} \mathrm{O}_{3}$ Nanorods. Phys. Chem. Chem. Phys., 2009, 11, 3718-3726.

(25) Quinzeni, I.; Ferrari, S.; Quartarone, E.; Mustarelli, P. Structural, Morphological and Electrochemical Properties of Nanocrystalline $\mathrm{V}_{2} \mathrm{O}_{5}$ Thin Films Deposited by Means of Radiofrequency Magnetron Sputtering. J. Power Sources 2011, 196, 10228-10233. 
(26) Li, L.; Steinera, U.; Mahajan, S. Improved Electrochromic Performance in Inverse opal Vanadium Oxide Films. J. Mater. Chem., 2010, 20, 7131-7134.

(27) Niu, C.; Han, C.; Zhao, Y.; Tian, X.; Guo, W.; Gu, Y.; Ma, L. Synthesis and Optical Property of Size-Tunable Vanadium Oxide Nano-Dandelions. J. Nanosci. Lett. 2013, 3: 27

(28) Chu, J., Kong, Z., Lu, D., Zhang, W., Wang, X., Yu, Y., Li, S., Wang, X., Xiong, S., Ma, J. Hydrothermal Synthesis of Vanadium Oxide Nanorods and their Electrochromic Performance. Mater. Lett., 2016, 166, 179.

(29) Kamalam, M.B.R.; Balachander, B.K.; Sethuraman, K. Solvothermal Synthesis and Characterization of Reduced Graphene Oxide/ Vanadium Pentoxide Hybrid Nanostructures. Mater. Today: Proceedings, 2016, 3, 2132-2140.

(30) Berezina, O., Kirienko, D., Pergament, A., Stefanovich, G., Velichko, A., Zlomanov, V. Vanadium Oxide Thin Films and Fibers Obtained by Acetylacetonate Sol-Gel Method. Thin Solid Films, 2015, 574, 15.

(31) Kawashima, T., Abe, D., Washio, K. Investigation on a Source of Dominant Donor in Vanadium-Doped ZnO Films Grown by Reactive RF Magnetron Sputtering. Mater. Sci. Semicond. Process., 2017, 70, 213-218.

(32) Huotari, J., Bjorklund, R., Lappalainen, J., Spetz, A. L., Pulsed Laser Deposited Nanostructured Vanadium Oxide Thin Films Characterized as Ammonia Sensors Actuator B-Chem., 2015, 217, 22-29.

(33) Mjejri, I.; Rougier, A.; Gaudon, M. Low-Cost and Facile Synthesis of the Vanadium Oxides $\mathrm{V}_{2} \mathrm{O}_{3}, \mathrm{VO}_{2}$, and $\mathrm{V}_{2} \mathrm{O}_{5}$ and Their Magnetic, Thermochromic and Electrochromic Properties. Inorg. Chem. 2017, 56, 1734-1741.

(34) Tong, Z.; Zhang, X.; Lv, H.; Li, N.; Qu, H.; Zhao, J.; Li, Y.; Liu, X.Y. From Amorphous Macroporous Film to 3D Crystalline Nanorod Architecture: A New Approach to Obtain High-Performance $\mathrm{V}_{2} \mathrm{O}_{5}$ Electrochromism. Adv. Mater. Interfaces 2015, 2, 1500230.

(35) Tong, Z.; Lv, H.; Zhang, X.; Yang, H.; Tian, Y.; Li, N.; Zhao, J.; Li, Y. Novel Morphology Changes From 3D Ordered Macroporous Structure to $\mathrm{V}_{2} \mathrm{O}_{5}$ Nanofiber Grassland and its Application in Electrochromism. Scientific Reports 2015, 5, 16864.

(36) Tong, Z.; Hao, J.; Zhang, K.; Zhao, J.; Su, B. L.; Li, Y. Improved Electrochromic Performance and Lithium Diffusion Coefficient in Three-Dimensionally Ordered Macroporous $\mathrm{V}_{2} \mathrm{O}_{5}$ Films. J. Mater. Chem. C, 2014, 2, 3651-3658.

(37) Lu, Y.R.; Wu, T.Z.; Chen, C.L.; Wei, D.H.; Chen, J.L.; Chou, W.C.; Dong, C.L. Mechanism of Electrochemical Deposition and Coloration of Electrochromic $\mathrm{V}_{2} \mathrm{O}_{5}$ Nano Thin Films: an In Situ X-Ray Spectroscopy Study. Nanoscale Res. Lett., 2015, 10, 387.

(38) Livage, J. Optical and Electrical Properties of Vanadium Oxides Synthesized From Alkoxides. Coord. Chem. Rev., 1999, 190-192, 391-403.

(39) Alsawafta, M.; Almoabadi, A.; Badilescu, S.; Truong ,V.V. Improved Electrochromic Properties of Vanadium Pentoxide Nanorods Prepared by Thermal Treatment of Sol-Gel Dip-Coated Thin Films. J .Electrochem. Soc., 2015, 162, H466H472.

(40) Costa, C.; Pinheiro, C.; Henriques, I.; Laia, C.A.T. Electrochromic Properties of Inkjet Printed Vanadium Oxide Gel on Flexible Polyethylene Terephthalate/Indium Tin Oxide Electrodes. ACS Appl. Mater. Interfaces 2012, 4, 5266-5275.
(41) Chalker, C.J.; An, H.; Zavala, J.; Parija, A.; Banerjee, S.; Lutkenhaus, J. L.; Batteas, J.D. Fabrication and Electrochemical Performance of Structured Mesoscale Open Shell $\mathrm{V}_{2} \mathrm{O}_{5}$ Networks. Langmuir 2017, 33, 5975-5981.

(42) Xiong, C.; Aliev, A.E.; Gnade, B.; Balkus, K. J.; Jr. Fabrication of Silver Vanadium Oxide and $\mathrm{V}_{2} \mathrm{O}_{5}$ Nanowires for Electrochromics. Acs Nano, 2, 2008, 293-301. 
TOC

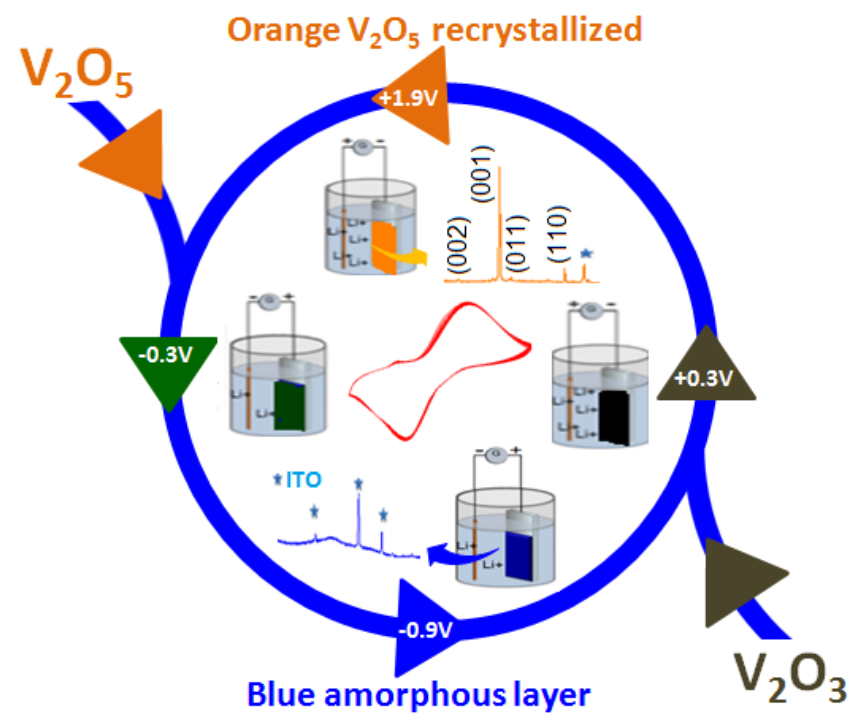

